JIA (Jurnal Ilmiah Akuntansi) • 6 (2), 379-393 • December 2021

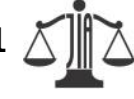

\title{
Model for Increasing Micro and Small Enterprises Performance through Optimizing the Role of BUMDes
}

\author{
Ni Kadek Sinarwati*, Luh Gede Kusuma Dewi, Febry Sugiantara, \\ Bhisma Putra Wasuka, Sayu Anggi Safitri \\ Universitas Pendidikan Ganesha, Jalan Udayana No. 11, Singaraja, Bali, \\ Indonesia \\ *nikadeksinarwati@undiksha.ac.id
}

\section{CITATION:}

Sinarwati, N. K., Dewi, L. G. K., Sugiantara, F., Wasuka, B. P., \& Safitri, S. A. (2021). Model for Increasing Micro and Small Enterprises Performance through Optimizing the Role of BUMDes. JIA (Jurnal Ilmiah Akuntansi), 6 (2), 379-393.

\section{ARTICLE HISTORY:}

\section{Received:}

October 16th, 2021

Revised:

November 23th, 2021

Accepted:

December 24th, 2021

DOI: $10.23887 /$ jia.v6i2.40379

\begin{abstract}
The micro and small enterprises (MSEs) performance inequality between districts/cities is a must-be-solved problem since inequality is one of the issues concerned in the Sustainable Development Goals. Much previous research on the role of Village-Owned Enterprises (Badan Usaha Milik Desa-BUMDes) performance revealed that BUMDes had a positive but not significant role. The reason is that BUMDes had not played an optimal role. This study aimed at building a model for improving the performance of Micro and Small Enterprises (MSEs) through optimizing the role of BUMDes. The data collected was primary data consisting of the causes of low MSEs performance, challenges, and opportunities for optimizing the role of BUMDes in improving MSE performance. Data were collected through a structured interview, in-depth interview, and Focus Group Discussion (FGD) methods. The results revealed that the model for improving MSEs' performance through optimizing the role of BUMDes was named the Dream House Model. This model requires that MSEs set a dream of experiencing a performance improvement that was set within three years. The main pillar in achieving this dream was that MSEs should revitalize and collaborate.
\end{abstract}

Keywords: MSEs; BUMDes; Performance.

\section{INTRODUCTION}

MSEs issues in Bali generally are not far away from what has been faced by Indonesia, which is a lack of ability of managerial, commitment in fulfilling the customer's demand, and low access towards financial sources.
The handling act towards the issue has been carried out by the government through varied MSEs empowerment programs, in the forms of fundings, partnerships, training, mentoring, and others. However, the empirical fact shows that the Balinese 
Table 1. MSEs Data of Balinese Province

\begin{tabular}{|c|c|c|c|c|c|c|}
\hline No & $\begin{array}{c}\text { Regency/ } \\
\text { City }\end{array}$ & $\begin{array}{c}\text { Investment } \\
\text { Value } \\
\text { (Rp) }\end{array}$ & $\begin{array}{c}\text { Production } \\
\text { Value } \\
\text { (Rp) }\end{array}$ & $\begin{array}{c}\text { Total } \\
\text { Manpower }\end{array}$ & $\begin{array}{c}\text { Total } \\
\text { Business } \\
\text { Unit }\end{array}$ & $\begin{array}{c}\text { Age } \\
\text { Average }\end{array}$ \\
\hline 1 & Jembrana & 73.933 .433 & 429.536 .074 & 8.712 & 1.750 & 18 \\
\hline 2 & Tabanan & 542.345 .198 & 567.236 .330 & 7.606 & 878 & 2 \\
\hline 3 & Denpasar & 283.412 .455 & 1.418 .492 .548 & 30.974 & 4.074 & - \\
\hline 4 & Badung & 72.444 .562 & 1.246 .268 .358 & 14.943 & 1.230 & 23 \\
\hline 5 & Gianyar & 2.989.867.354 & 4.841 .849 .850 & 15.058 & 943 & 15 \\
\hline 6 & Bangli & 24.371 .071 & 363.330 .010 & 11.741 & 4.167 & 14 \\
\hline 7 & Karangasem & 25.737 .579 & 32.213 .224 & 4.210 & 512 & 16 \\
\hline 8 & Klungkung & 29.274 .729 & 92.890 .481 & 4.617 & 461 & 16 \\
\hline 9 & Buleleng & 22.012 .121 & 183.092 .572 & 6.220 & 977 & 15 \\
\hline
\end{tabular}

Source: Industry and Trade Office of Bali Province, 2017

- data is not available

MSEs have not developed optimally (Ayu et al., 2015)

The presence of MSEs in Bali is one of the supports for the tourism sector, which is primed in increasing the Original Local Government Revenue. The value investment data, production value, total manpower, the number of business units, and the average age of the MSE in each Regency/City in the Province of Bali are presented in Table 1.

The data in Table 1 reveals that value production and low labor absorption are found in Karangasem Regency. The data proves that the MSEs performance in Karangasem Regency is low compared to other regencies. The performance problem of MSEs in the Karangasem Regency becomes important to be analyzed and find the solution, remembering the gap is one of the issues studied on the Sustainable Development Goals (SDGs).

The main issue investigated in this study was the low performance of MSEs in the Karangasem Regency. The low MSEs performance indicator is the low-value production. The cause of low production value is the lack of capital. This issue must not have occurred since Karangasem Regency has many microfinance agencies, one of those is Village-Owned Enterprises (BUMDes) which offers loans with low interest and easy conditions. Ideally, BUMDes can role optimally in increasing MSEs performance, however, the reality proves that Karangasem Regency BUMDes have not optimally performed in increasing the performance of MSEs. Sinarwati et al. (2020) found that BUMDes has 
been positively performed but not significant yet towards the performance of craftsmen in the Karangasem Regency. The presence of BUMDes should help the MSEs in the village in the capital and marketing fields. Generally, the research aimed at increasing village economy rate through the optimization role of BUMDes in improving MSEs performance. The development of an improved performance model through the optimization of BUMDes role is a solution in improving MSEs performance to the village economy rate.

This study aimed at building a model for improving the performance of MSEs through optimizing the role of BUMDes. Ideally, the presence of BUMDes is expected to improve the village economy, but empirical facts based on research findings by (Sinarwati et al., 2020; Sinarwati \& Marhaeni, 2019) BUMDes have a positive but not significant role in the performance of craftsmen. These findings motivated this researcher to build a model for improving the performance of MSEs through optimizing the role of BUMDes. This research was urgently carried out considering that at this time the Ministry of Villages PDTT through the Minister of Village Regulation Number 13 of 2020 concerning Priorities for
Use of Village Funds in 2021 stipulates that one of the priorities for the use of village funds is to develop BUMDes, so the role of BUMDes must be optimized in improving the performance of MSEs.

\section{LITERATURE REVIEW}

Micro Small Enterprise (MSE) for Indonesia is the main foundation of its economic development. Since 2011 and 2012, businessmen in MSE are the majority amounted to $99,99 \%$ of the total businessmen in Indonesia. From its development of work field, MSE also shows its domination. The total amount of workforce who work in the business sector amounted to $97,24 \%$ in 2011 and 97,16\% in 2012 work in the MSE sector. From the description of the dominance of MSE in the number of business entities and employment, it is more specifically dominated by microenterprises. This is possible considering that micro-business entities cover both the formal and informal sectors with a low barrier to entry and exit characteristics. This micro-enterprise-scale entity also plays a strategic role as a people's safety net in facing crises and economic turbulence. Thus, the existence of reliable and strong MSE is the main capital for economic development, as well as being a 
bearing in the face of global economic turmoil. Arief et al. (2017) revealed the definition of the MSE based on the number of workers, for small businesses it was five to nineteen people, while for medium-sized businesses it was between twenty to ninety-nine workers. The definition of the MSE above is following the definition of the MSE used in the Asian Development Bank (Larasati, 2011).

MSE has its specific characteristics which differentiate it from the bigger ones, including characteristics that differentiate the micro-business, small business, and medium business. stated that from the workforce more than one-third (around 34,5\%) of MSE is managed by workforce aged over 45 years old, and only around $5,2 \%$ of MSE businessmen aged below 25\%. revealed that the workforce needed by small industries does not demand high formal education. Most of the needed workforce in this industry is based on experience (learning by doing) related to historical factors (path dependence). Tambunan (2012) again revealed that the businessmen's structure based on their formal education implies a positive relationship between the businessmen's average education with the business scale. This means that the bigger the business scale is, which is generally associated positively with the complexity rate of the business which needs high skills, broad business knowledge, the more businessmen with tertiary formal education.

Performance is an individual or group member of work. The performance of work cannot be limited to the responsible members functionally or structurally. But it is limited to all organization members. Description of performance is including three important components, which are purposes, measurement, and assessment. The purposes' determination from each organization unit is a strategy in increasing work performance. The purpose will give direction and influence how to work behavior should be expected on each of the personnel. However, purposes determination is not enough, thus, measurement of expected work performance is needed.

According to Notoatmodjo (2009) there are some theories about factors influencing work performance, abbreviated into "ACHIEVE' which means Ability (abilities that can be developed), Capacity (abilities that are determined/limited), Help (assistance to make a realization out of the performance, Incentive (material and 
non-material),

Environment

(atmosphere of the workforce), Validity (guidance and job description), and Evaluation (feedback from the work result).

Literature reveals that there is some previous research carried out about improvement model of MSE performance, such as Bismala \& Handayani (2014) designed a SWOT analysis-based MSE management model resulted in a strategy to provide training in all aspects, given the lack of knowledge owned by MSEs, and to help introduce information technology as an information technology-based marketing approach. Irmawati et al. (2013) designed a finance inclusive model on Small and Medium Enterprises (SME) based on villages resulted in the inclusive model on financial for Batik UMKM in Klaten Regency, that is the entry of financial institutions in terms of capital is in the form of low-interest loans which are then provided with assistance by financial institutions.

Setiyadi et al. (2011) researched the determination of business sustainability strategy in culinary MSE by using the SWOT AHP method resulting in strategies that consist of opening local branches and conducting partnerships. Senen \& Sidharta researched Strategic Management Approach
Study Model in SME in Bandung can be done by developing strategy continued by SWOT analysis. The performance improvement of MSE especially in villages can be carried out by optimizing the roles of BUMDes. BUMDes is a social entrepreneur institution built to manage the village's potentials to increase the villagers' prosperity.

Research about BUMDes was carried out by Widodo (2016) entitled "Badan Usaha Milik Desa as An Alternative to Village Income", concluded that commitment to building BUMDes is needed to increase village economic competitiveness. Sayuti (2011) researched BUMDes development driving the village's economic potential in poverty alleviation in Donggala Regency, resulting in BUMDes characteristics as an institution in empowering the community in form of a law agency, as the center of villager's economic activities, as one of the village incomes, and serves the villagers.

The Research on Craftsmen Performance Improvement Models Through Optimizing Roles of BUMDes is an elaboration from the previous research carried out which were Sinarwati \& Marhaeni (2019) who analyzed SME improvement performance based on SWOT analysis, Sinarwati et al. (2020) who analyzed the roles of BUMDes in the village's 
development in Karangasem Regency, and Sinarwati et al. (2020) who analyzed the roles of BUMDes performance, entrepreneurship, and prosperity of craftsmen in Karangasem Regency.

\section{METHOD}

The research used Research and Development scheme which aimed at building an MSE performance model through the optimization of BUMDes roles. MSE performance indicators in this research are profit increase and increase in employment. The data collected is the cause of MSE's low performance and the cooperation opportunity between MSE and BUMDes. The data types used were primary data such as MSE performance and BUMDes roles which had not been optimal yet.

The method of data collection was the structured interview, in-depth interview, and Focus Group Discussion (FGD) whihwas attended by MSE and BUMDes experts, BUMDes managers, and MSE people in Karangasem Regency. The respondents of the research were determined by purposive sampling technique with some criteria, such as respondents who were actively in MSE and BUMDes with the biggest capital in each district. The modeling stage used the research stages of Tahwim and Kusumaningsih, 2018. There are some stages mentioned, firstly analyzed the cause of MSE low performance through fishbone analysis, carried out the in-depth interview and Focus Group Discussion. Secondly, did SWOT analysis to know opportunities and threats of MSE-BUMDes collaboration in optimizing roles of BUMDes in the improvement of MSE performance. Thirdly, building model design. Fourthly, arrange the main indicators and performance of target improvement.

\section{RESULTS AND DISCUSSION}

The results of the interview and the Focus Discussion (FGD) revealed several problems faced by MSE especially in the village in Karangasem Regency. Below is the fishbone analysis figure (Figure 1).

The SWOT analysis to investigate the threats and opportunities of MSE and BUMDes collaboration in improving MSE performance is presented in Table 2. Regarding the SWOT matrix arrangement carried out by (Amalia et al., 2017) and based on structured or in-depth interview results with the respondents, thus, the SWOT analysis towards the craftsmen in Karangasem Regency are: 


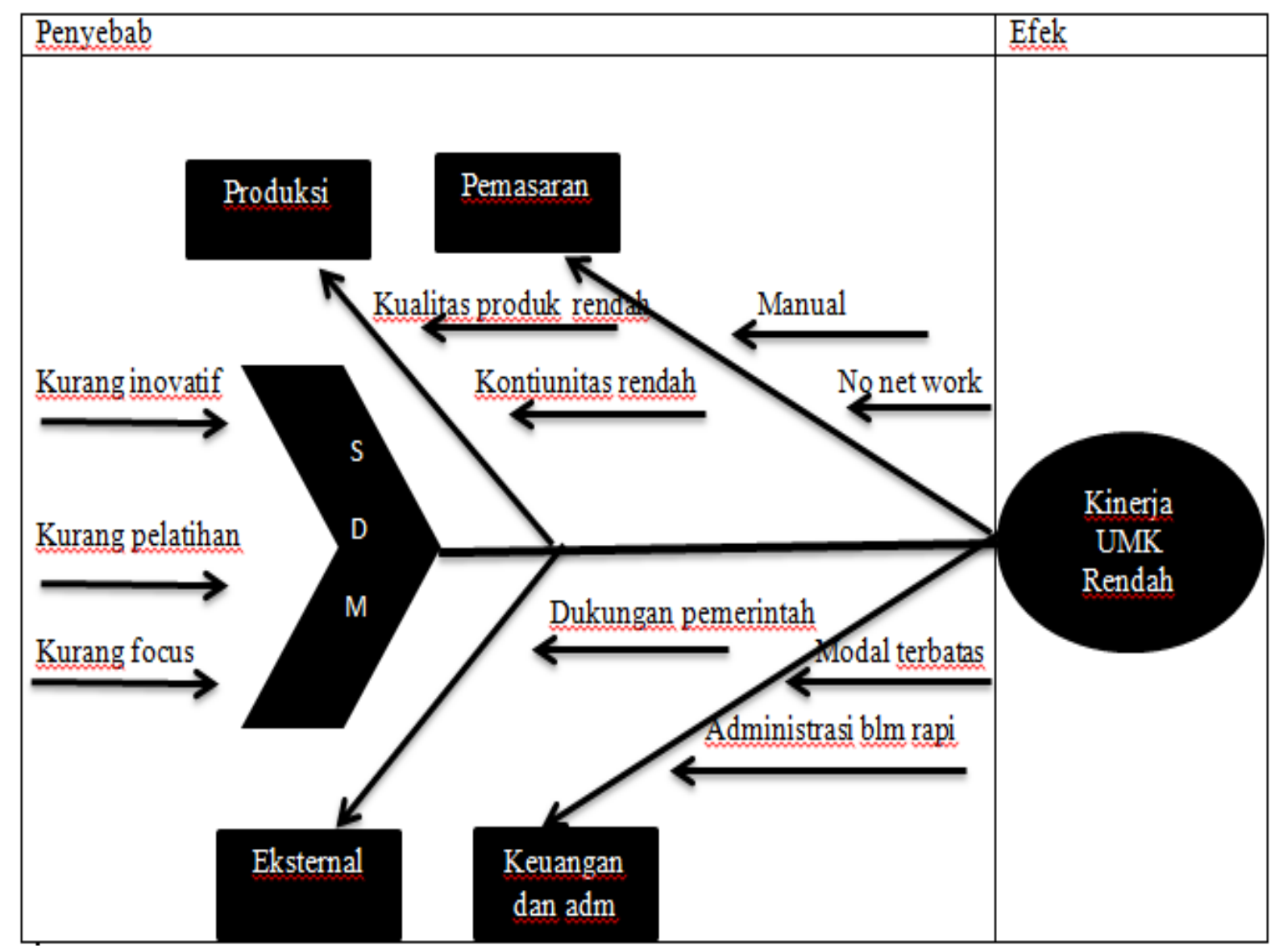

Figure 1. The Cause of the Low Performance of MSE

1) Write down external opportunities

The external opportunities faced by MSE in running its business is:

- Get capital helps in form of soft loans from BUMDes

2) Write down external threats The external threats faced by the craftsmen in running their business are:

- Tight competition

- Slow economic growth

3) Write down internal strengths

Internal strengths owned by MSE people in running the business are:
- unlimited raw materials with relatively low price

- unlimited workforce with relatively low wage

4) Write down internal weaknesses

Internal weaknesses owned by the craftsmen in running the business are:

- lack of qualified workforce

- monotonous and noninnovative product design

- limited market information

- Match the internal strengths with the external opportunities 
Table 2. SWOT Matrix of Performance Improvement through Optimizing Roles of BUMDes

\begin{tabular}{|c|c|c|c|}
\hline & & STRENGTHS (S) & WEAKNESSES (W) \\
\hline $\begin{array}{l}\text { EXTERNAL } \\
\text { FACTORS }\end{array}$ & a) & $\begin{array}{l}\text { Unlimited raw } \\
\text { materials with } \\
\text { relatively low price } \\
\text { Unlimited workforce } \\
\text { with relatively low } \\
\text { wage }\end{array}$ & $\begin{array}{lr}\text { Lack of qualified workforce } \\
\text { Monotonous r and } \\
\text { noninnovative } \\
\text { design } \\
\text { Limited market information }\end{array}$ \\
\hline $\begin{array}{l}\text { OPPORTUNITIES }(\mathrm{O}) \\
\text { a) The presence of human } \\
\text { resources } \\
\text { b) The presence of human } \\
\text { resources in villages } \\
\text { c) Capital help from } \\
\text { BUMDes }\end{array}$ & b) & $\begin{array}{l}\text { SO STRATEGIES } \\
\text { Utilize the funding help a) } \\
\text { from BUMDes and } \\
\text { optimize the presence } \\
\text { of workforce to develop } \\
\text { business } \\
\text { Maintain the product b) } \\
\text { quality by using } \\
\text { training resources from } \\
\text { the government }\end{array}$ & $\begin{array}{l}\text { WO STRATEGIES } \\
\text { Follow the training program } \\
\text { carried out by the } \\
\text { government to improve the } \\
\text { quality of workforce and } \\
\text { product innovation } \\
\text { Preparation of marketing } \\
\text { programs online or via the } \\
\text { web by optimizing software } \\
\text { assistance from BUMDes }\end{array}$ \\
\hline $\begin{array}{l}\text { THREATS }(\mathrm{T}) \\
\text { a) Tight competition } \\
\text { b) The slow growth of the } \\
\text { economy }\end{array}$ & a) & $\begin{array}{l}\text { ST STRATEGIES } \\
\text { Win the competition by a) } \\
\text { producing higher } \\
\text { quality products b) } \\
\text { compared to } \\
\text { competitors' products } \\
\text { Optimizing the use of } \\
\text { relatively cheap raw } \\
\text { materials and labor to } \\
\text { be able to survive amid } \\
\text { the economic } \\
\text { downturn }\end{array}$ & $\begin{array}{l}\text { WT STRATEGI } \\
\text { Increasing } \\
\text { creativity and innovation } \\
\text { Looking for new market } \\
\text { share }\end{array}$ \\
\hline
\end{tabular}

Source: interview results with MSE people and BUMDes management

and note the SO strategies in the determined cell

a) Match the internal weaknesses with the external opportunities and note the WO strategies in the determined cell

b) Match the internal strengths with the external threats and note the ST strategies in the determined cell

c) Match the internal weaknesses with the external threats and note the WT strategy in the determined cell
The SME SWOT matrix of the craftsmen arranged based on the steps according to (Amalia et al., 2017) presented in Table 2.

After being analyzed, opportunities and threats of MSE performance improvement by optimizing roles of BUMDes carried out through MSE-BUMDes collaboration, thus, the next steps are to arrange an improvement model of MSE improvement performance using the Dream House Model developed by Tahwin \& Kusumaningsih (2018). 


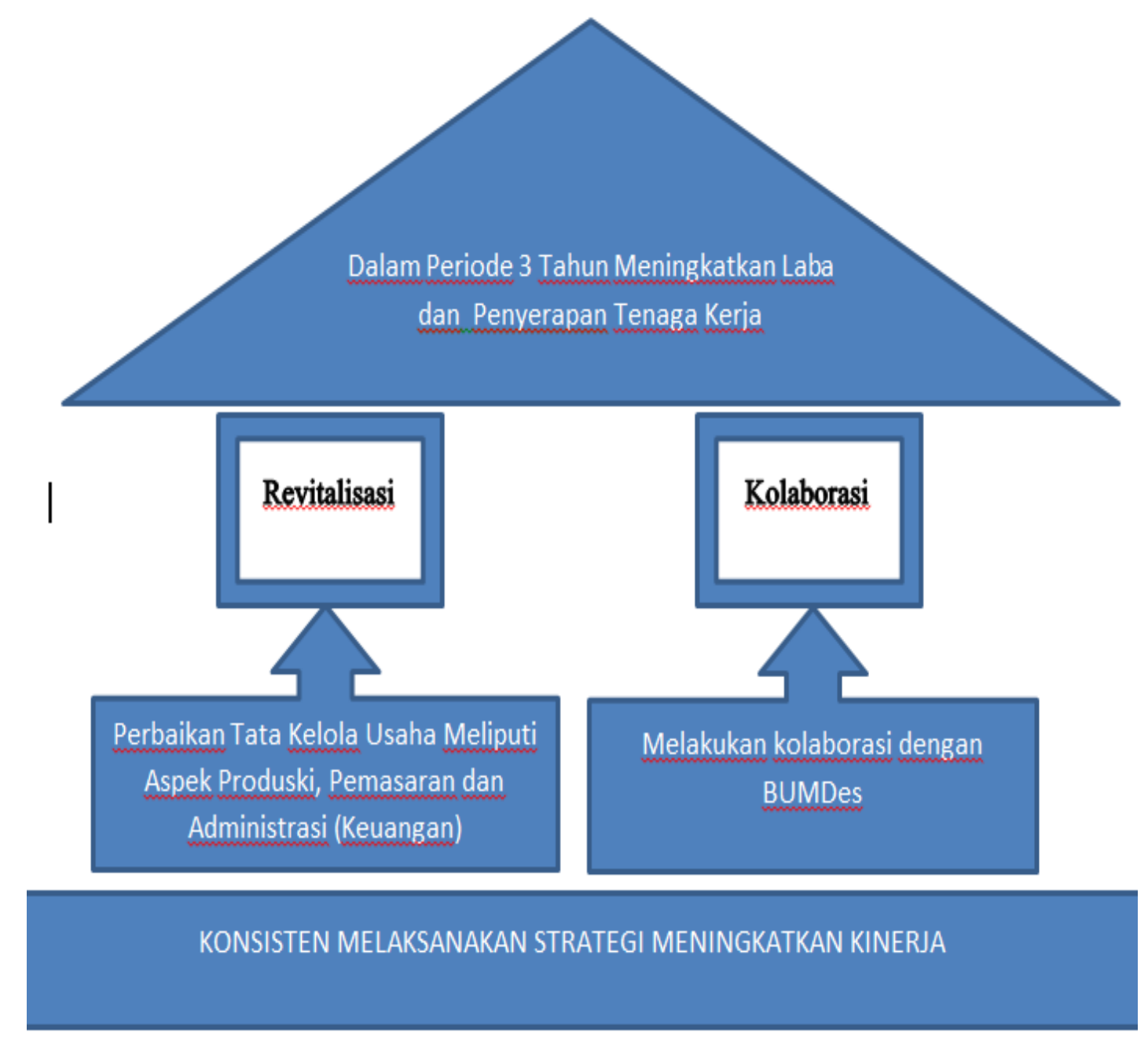

Figure 3. Form of Dream House Model

The model determines the vision and mission of an MSE in a certain time which in this study was 3 years. The dream in this context was to improve performance using profit improvement indicators and increase employment. The two main pillars of achievement of dreams are revitalization and collaboration. A solid foundation for achieving dreams is consistently executing strategy. The form of the Dream House model The MSE Performance Improvement
Model through Optimizing the Role of BUMDes is presented in Figure 3 Indicators of performance improvement determined that would be reached within 3 years was the profit increase and workforce in improvement. There were two pillars in which the MSE carried out, such as revitalization and collaboration. Revitalization here means that the MSE does a reparation in its management of business through doing the reparation in the 
production, marketing, and administration/financial. The reparation in the production field was carried out by improving product innovation, keeping the continuity of product, and determining product standard that covers raw materials and production process standard so that the product quality improves and has high competition values (Tahwin \& Kusumaningsih, 2018).

Marketing revitalization can be done through online marketing, finding marketing independently without depending on one distributor, forming a connection to broaden the market. Administration and financial revitalization can be done continuously noting transactions of business, arranging computerized financial reports, and separating between business and personal assets. A clear and neat business administration is one of the requirements to get loans or credits from a financial agency. The continuous business financial arrangement has its advantages in giving information of business results, cash flow, and development of invested capital. Business revitalization can be carried out by joining the workshop to improve human resources competency.

The second most important pillar that can be done by MSE to reach its dream is by collaborating with Badan Usaha Milik Desa (BUMDes). Optimization roles of BUMDes in increasing performance can be done by the presence of BUMDes as an economic platform for MSE products in rural areas. BUMDes which is a social village entrepreneur agency was not present as a competitor and predator of economic village business. With the presence of BUMDes in the chain of activities, MSE people in the village become a village economic forum, for example, BUMDes acts as a provider of raw materials for handicraft products, supports funds/lenders, and as distributor agents to increase sales of MSE products.

The results of the next Dream House Model design were used to develop Key Performance Indicators (KPI) which was a measure of the success of an operational strategic goal and target. The strategic target which was the vision/dream that MSE wants to achieve was performance improvement. A detailed description of the strategic objectives, Performance Indicators, Key Performance Indicators, and Realization targets are presented in Table 3. 
Table 3. Key Performance Indicators MSE Performance Improvement

\begin{tabular}{|c|c|c|c|c|c|c|}
\hline \multirow[b]{2}{*}{ 1) } & \multirow{2}{*}{$\begin{array}{l}\text { Indicators } \\
\text { Profit } \\
\text { Improvement }\end{array}$} & \multirow{2}{*}{$\begin{array}{r}\text { Target } \\
\text { Revitalization on: }\end{array}$} & \multirow{2}{*}{$\begin{array}{l}\text { Key Performance Indicators } \\
\text { A. IKU, Product and } \\
\text { Production: } \\
\text { 1) Improvement in Product }\end{array}$} & \multicolumn{3}{|c|}{$\begin{array}{c}\text { Achievement Target } \\
\text { in } 3 \text { Years }(\%)\end{array}$} \\
\hline & & & & 022 & 023 & 024 \\
\hline \multirow[t]{12}{*}{ 2) } & $\begin{array}{l}\text { Employment } \\
\text { Improvement }\end{array}$ & $\begin{array}{l}\text { B. Marketing } \\
\text { C. Administratio } \\
\mathrm{n} \quad \text { and }\end{array}$ & $\begin{array}{l}\text { Design Innovation } \\
\text { 2) Product Standard } \\
\text { Determination }\end{array}$ & $0 \%$ & $0 \%$ & $0 \%$ \\
\hline & & Financial & $\begin{array}{l}\text { 3) Production Standard } \\
\text { Determination } \\
\text { B. IKU, Marketing }\end{array}$ & $0 \%$ & $0 \%$ & $00 \%$ \\
\hline & & & $\begin{array}{l}\text { 1) Online Marketing } \\
\text { 2) Find the market } \\
\text { independently without } \\
\text { depending on the } \\
\text { distributor }\end{array}$ & $0 \%$ & $0 \%$ & $00 \%$ \\
\hline & & & $\begin{array}{l}\text { 3) Forming Connection } \\
\text { C. IKU, Administrasion and } \\
\text { Financial }\end{array}$ & $0 \%$ & $0 \%$ & $00 \%$ \\
\hline & & & $\begin{array}{l}\text { 1) Takes note regularly of all } \\
\text { business transaction }\end{array}$ & $0 \%$ & $0 \%$ & $0 \%$ \\
\hline & & & $\begin{array}{l}\text { 2) Financial Report } \\
\text { Arrangement }\end{array}$ & & & \\
\hline & & & $\begin{array}{l}\text { 3) Dividing capital and } \\
\text { personal belongings }\end{array}$ & $0 \%$ & $0 \%$ & $00 \%$ \\
\hline & & & & $0 \%$ & $0 \%$ & $00 \%$ \\
\hline & & & & $0 \%$ & $0 \%$ & $00 \%$ \\
\hline & & & & $0 \%$ & $0 \%$ & $00 \%$ \\
\hline & & Collaboration & $\begin{array}{l}\text { Cooperation with BUMDEs } \\
\text { A. Arranging MoU } \\
\text { B. Implementing MoU }\end{array}$ & $0 \%$ & $0 \%$ & $00 \%$ \\
\hline & & & & $0 \%$ & $0 \%$ & $00 \%$ \\
\hline
\end{tabular}

The cause of the low performance of MSE in Karangasem Regency were internal and external factors similar to the literature findings (Hendratmoko, 2021; Herwiyanti \& Rafinda, 2021; Mokodompit et al., 2019; Munizu, 2010; Sugis \& Kartika, 2014). The improvement of MSE performance especially in the villages, one of which is having cooperation and collaboration with Badan Usaha Milik Desa (BUMDes), a business agency that has purposes in developing village economy.

Performance improvement of model arrangement is begun with analyzing the cause of low 
performance, continued by doing the SWOT analysis in understanding the cooperation opportunities BUMDes in improving the roles of BUMDes. The next step is building the Dream House Model. The last step is determining Key Indicators Performance and performance improvement target of the MSE. The stages of data analysis refer to the research of (Sinarwati \& Marhaeni, 2019; Tahwin \& Kusumaningsih, 2018). Optimizing the role of BUMDes in improving MSE performance is realized by establishing BUMDesMSE collaboration. BUMDes is present in the MSE business chain as a forum in the production and distribution process of MSE products (Suryanto, 2021). The MSE-BUMDes collaboration in running the villagebuilding economy is the embodiment of the 17th Village SDGs, namely the Village Building Partnership (Taufik, 2020).

\section{CONCLUSION, IMPLICATION AND LIMITATION}

The results of interviews with micro-enterprises and the results of Focus Group Discussions show that the cause of the low performance of MSE, especially in rural areas, is the problem of Human Resources/HR who are less innovative, less focused, and have never attended the training.
Product and production problems ie low quality and continuity. Marketing problems, namely marketing is done manually and does not have a network to strengthen marketing, administrative and financial problems, namely limited capital and untidy administration and external causes, namely government support.

The MSE performance improvement model through optimizing the role of BUMDes was built by analyzing the causes of the low performance of MSE using fishbone analysis, conducting a SWOT analysis to find out the opportunities and challenges of the MSE-BUMDes collaboration to improve the performance of MSE through optimizing the role of BUMDes. The next step is to build a model using the Dream House Model. The final step is to determine the Key Performance Indicators and MSE Performance Achievement Targets.

The creation of a research product that is useful to society is the goal of research work. The specific objective of this research is to build a model for improving the performance of MSE through optimizing the role of BUMDes. The general objective achieved is to improve the performance of MSE with indicators of increasing profits and increasing employment. The suggestions put 
forward to achieve the general objectives of the research are addressed to MSE actors consistently carrying out revitalization and collaboration to achieve the vision of improving performance. BUMDes consistently becomes MSE's partner and becomes a forum for MSE's products, especially in rural areas.

The managerial implication of this research is that the low performance of MSE is mostly caused by internal factors, namely from within MSE, namely HR, production, marketing, and administration issues, the implication is that MSE actors should revitalize or improve business governance. Support from BUMDes, the government, and universities are expected to help MSE achieve its dreams.

\section{ACKNOWLEDGEMENT}

The author would like to thank the Institute for Research and Community Service (LP2M) Universitas Pendidikan Ganesha because this article is a summary of research funded by LP2M Universitas Pendidikan Ganesha.

\section{REFERENCES}

Amalia, A., Wahyu, H., \& Agung, B. (2017). Analisis Strategi Pengembangan Usaha Pada UKM Batik Semarangan Di Kota Semarang. Jurnal Ilmu Administrasi Dan Bisnis.
Arief, R., Yani, I., \& Rienna, O. (2017). Strategi Pengembangan Usaha Kecil menengah Sektor Industri Pengolahan. Artikel. Www. Google Cendekia.

Ayu, W. I. G., Sri Budhi, I. M. K., Saskara, I. A., \& Yasa, I. G. W. M. (2015). Pengaruh Modal Sosial Terhadap Orientasi Kewirausahaan dan Biaya Transaksi Untuk Meningkatkan Kinerja Usaha Pada UKM Kerajinan Kayu di Provinsi Bali. Disertasi. Universitas Udayana.

Bismala, L., \& Handayani, S. (2014). Model Manajemen UMKM Berbasis Analisis SWOT. Naskah Lengkap Seminar Nasional PB3I ITM.

Hendratmoko. (2021). FAKTORFAKTOR YANG MEMPENGARUHI KINERJA UMKM DI INDONESIA. JOBS (Jurnal Orientasi Bisnis Dan Enterpreneurship), 2(1). https://doi.org/https:/ /academi cjournal.yarsi.ac.id/index.php/j obs/article/view/1782 DOI: https://doi.org/10.33476/jobs.v 2i1.1782

Herwiyanti, E., \& Rafinda, A. (2021). Determinant Factor of Small Medium Enterprises to Access Bank Credit. JIA (Jurnal Ilmiah Akuntansi), 6(1), 37-45. https://doi.org/https:/ / ejournal .undiksha.ac.id/index.php/JIA/ article/view/29907

Irmawati, S., Delu, D., \& Wahyu, P. D. (2013). Model Inklusi Keuangan Pada UMKM Berbasis Pedesaan. Jurnal of Economics and Policy (JEJAK).

https://doi.org/http://journal.u nnes.ac.id/nju/index.php/jejak

Mokodompit, M. P., Syarifuddin, \& Mutiana, S. (2019). IDENTIFIKASI FAKTOR YANG 
MEMPENGARUHI KINERJA

UMKM. Profita: Komunikasi Ilmiah Akuntansi Dan Perpajakan, 12(2), 242-248. https://doi.org/https://publika si.mercubuana.ac.id/index.php/ profita/article/view/profita.2019 .$v 12.02 .005$

Munizu, M. (2010). Pengaruh FaktorFaktor Internal dan Eksternal Terhadap Kinerja Usaha Mikro dan Kecil (MSB) di Sulawesi Selatan. Jurnal Manajemen Dan Kewirausahaan, 12(1), 33-41.

Notoatmodjo, S. (2009). Kesehatan Masyarakat "Seni dan Imu." Rineka Cipta.

Sayuti, H. M. (2011). Pelembagaan Badan Usaha Milik Desa (BUMDs) Sebagai Penggerak Potensi Ekonomi Desa Dalam Upaya Pengentasa Kemiskinan Di Kabupaten Donggala. Jurnal Academica Fisip Untad, 3(2), 1411-3341.

Senen, M., \& Sidharta, I. (2013). Model Kajian Pendekatan Manajemen Strategik Dalam Peningkatan Sektor UMKM di Kota Bandung. Jurnal Computech \& Bisnis, 7(1), 56-66.

Setiyadi, S., Kifayah, A., \& Taufiq, A. (2011). Penentuan Strategi Sustainability Usaha Pada UKM Kuliner Dengan Menggunakan Metode SWOT- AHP. Jurnal Imiah Teknik Industri, 10(2).

Sinarwati, N. K., AAIN, M., Utama, I. M. S., \& Budhi, M. K. S. (2020). Does Entrepreneurship Supply Chain Management Mediate the Effect of VOE Resources and Social Capital to Performance of Craftsmen? 9(5), 1695-1701. https://doi.org/https://ojs.excel ingtech.co.uk/index.php/IJSCM /article/view/5639/2932
Sinarwati, N. K., \& Marhaeni, A. (2019). The Role of Village Own Enterprises to Rural Development. South East Asia Journal of Contemporary Business, Economics and Law. The Role of Village Own Enterprises to Rural Development. South East Asia Journal of Contemporary Business, Economics and Law, 18(5), 77-83. https://doi.org/https://seajbel.c om/wpcontent/uploads/2019/04/seajb el5-VOL18_227

Sugis, S. R., \& Kartika, L. (2014). Model Peningkatan Kinerja Usaha Kecil Menengah melalui Pengembangan Modal Insani dan Modal Sosial (Studi Kasus UKM Makanan dan Minuman di Kota Depok). Accelerating the World's Research.

https://doi.org/https:/ /123dok. com/document/4yr7k0pqpeningkatan-kinerja-menengahmelalui-pengembangan-sosialmakanan-minuman.html.

Suryanto. (2021). FGD Model Peningkatan Kinerja Melalui Optimalisasi Peran BUMDes. Materi FGD Tanggal 25 September 2021. Penanggap Ahli BUMDes Atas Nama Rudy Suryato.

Tahwin, M., \& Kusumaningsih, N. (2018). MODEL PENINGKATAN KINERJA USAHA KECL DAN MENENGAH MENGGUNAKAN THE DREAM HOUSE MODEL (Studi Kasus Industri Batik Tulis Lasem Kabupaten Rembang).

Tambunan, T. (2012). UMKM di Indonesia. In Ghalia Indonesia.

Taufik, M. (2020). PRIORITAS PENGGUNAAN DANA DESA TAHUN 2021 DAN UPAYA REVITALISASI BUMDES. 
JIA (Jurnal Ilmiah Akuntansi) • 6 (2), 379-393• December 2021

$\begin{array}{lr}\text { Jakarta: } & \text { KEMENTERIAN } \\ \text { PEMBANGUNAN } & \text { DAERAH } \\ \text { TERTINGGAL } & \text { DAN } \\ \text { TRANSMIGRASI, 55. } & \end{array}$

Widodo, I. S. (2016). Badan Usaha Milik Desa Sebagai Salah Satu Alternatif Sumber Pendapatan Desa Berdasarkan UndangUndang No. 6 Tahun 2014 Tentang Desa. Jurnal Panorama Hukum, 1(1), 2527-6654. 